\title{
PROPERTY TAXES REFORMS IN THE CZECH REPUBLIC
}

On January 1, 2008, many new changes in the Czech tax legal regulation came into force mainly with the special act - the Act on Public Budgets Stabilization, informally called Topolánek's Rucksack. This act is comprised of 50 parts; every part brings new or amended regulations on particular institutions like taxes, health and social insurance, Czech General Health Insurance Company, many social and labour aspects, etc. It is not a very clear act and there is a question if one act can include so many different parts. The Constitutional Court of the Czech Republic (after many problems and with many alternative opinions) confirmed that ${ }^{1}$.

This act introduced absolutely new, and in many aspects, revolutionary principles of income taxes. The tax rate of personal income tax is linear of $15 \%$ only and the tax rate of corporate income tax is linear of $21 \%$ in 2008, $20 \%$ in 2009 and $19 \%$ in 2010 . Especially, the $15 \%$ tax rate may sound great for employees ${ }^{2}$. However, the tax base (partial tax base) shall be defined as income from dependent activity or function benefits increased by sums of social security insurance premium, contribution to the state employment policy and general health insurance premium that must be paid by the employer according to special regulations. ${ }^{3}$ The "social security" paid by employer is very high $-35 \%$ of the gross income. It means that the tax is calculated like that:

Gross Income * 1,35 (Social Security $)=$ Tax Base $* 0,15($ Tax Rate $)=$ Personal Income Tax.

Tax (gross tax) can be reduced to a large extent due to the tax reductions such as: the basic one of $24840 \mathrm{CZK}$ can be used for each taxpayer and the other reductions depend on social aspects (handicapped persons, students, spouses without incomes,

\footnotetext{
See the Judgment of the Constitutional Court of the Czech Republic no. 24/07.

Till the end of 2007 the tax rate was percentual progressive between $12-32 \%$, since the beginning of 2009 it will be $12,5 \%$ only.

3 Till the end of 2007 the tax base was defined as income from a dependent activity or function benefits reduced by sums of social security insurance premium, contribution to the state employment policy and general health insurance premium that must be paid by the employee according to special act. The "social security paid by employee was $12,5 \%$ of the gross income.
} 
children). To calculate the net income of the taxpayer, it is necessary to deduct social insurance paid by employee of $12,5 \%$ and tax from the gross income.

Thanks to these changes the state collects less money than before and transfers less money to the municipalities, too. Therefore, the legislators provided municipalities with new possibilities in the area of real estate tax to make compensation of redistributed incomes from income taxes.

\section{Real Estate Tax}

Historically, Czech municipalities did not have many possibilities to influence real estate tax. After the tax reforms in 2008 they have more powers to do that, but they still do not administrate this tax; it is administered by the state offices called financial offices.

And what are the possibilities of municipalities in the Czech Republic to influence real estate tax? Already several years, when eliminating consequences of natural disaster, a municipality may, by its generally binding ordinance, fully or partially (as a percentage) exempt the real estates, which are located within its area and which were affected by a natural disaster, from the real estate tax for a period of up to five years. The exemption can be effective not only for the year when the natural disaster occurred and for the following years after that, but even for the preceding taxable period. It is a problematic situation as the taxpayer is obliged to file his/her tax return by 31 January of the taxable period and in that case $\mathrm{s} / \mathrm{he}$ has to file supplementary tax return. To tell the truth, this kind of exemption is not very popular and often applied. If there is a natural disaster, the municipality needs more money than usual and this exemption is not offered. Moreover, it is difficult to estimate which real estates were affected by a natural disaster (for example flats in the first floor were damaged, but flats in the fourth flour are all right).

The arable lands, hop-gardens, vineyards, orchards and permanent grass growths can be newly exempt by municipality's generally binding ordinance in 2009. This exemption cannot be applied to lands in developed area and municipal build-up area if the ordinance stipulates so and if these lands are marked in the ordinance by the parcel number and the cadastre area. Taking into consideration the reaction of many mayors it will not be used a lot: small villages with many lands that can be exempt would lose a lot of money and in cities there are not many lands like that.

Coefficient called location rent - a coefficient according to the number of inhabitants - is used only for several kinds of real estates: development lands, residential buildings, other structures that provide facilities for residential buildings, flats and non-residential premises not used for running business and garages. It 
multiplies the standard tax rate. The basic value of the coefficient is set in the act and the municipalities have the right to increase or reduce a basic coefficient by means of a generally binding ordinance:

Table 1: Location Rent

\begin{tabular}{|l|c|c|c|c|c|}
\hline \multirow{2}{*}{ Number of inhabitants / Municipality } & \multicolumn{5}{|c|}{ Coefficient } \\
\cline { 2 - 6 } & Basic & \multicolumn{3}{|c|}{ Reduced } & Increased \\
\hline$<1000$ & 1,0 & - & - & - & 1,4 \\
\hline$>1000<6000$ & 1,4 & - & - & 1,0 & 1,6 \\
\hline$>6000<10000$ & 1,6 & - & 1,0 & 1,4 & 2,0 \\
\hline$>10000<25000$ & 2,0 & 1,0 & 1,4 & 1,6 & 2,5 \\
\hline$>25000<50000$ & 2,5 & 1,4 & 1,6 & 2,0 & 3,5 \\
\hline$>50000+$ Františkovy Lázně, \\
$\begin{array}{l}\text { Luhačovice, Mariánské Lázně, } \\
\text { Poděbrady }\end{array}$ & 3,5 & 1,6 & 2,0 & 2,5 & 4,5 \\
\hline Prague & 4,5 & 2,0 & 2,5 & 3,5 & 5,0 \\
\hline
\end{tabular}

This coefficient is used by many Czech municipalities and it has quite a long tradition especially due to its fiscal function. There were two more basic levels of location rent of 0,3 and 0,6 before the Act on Public Budgets Stabilization was introduced.

Municipal coefficient can be used for some buildings if the location rent cannot be used. i.e. houses and family houses used for individual recreation, other structures that provide facilities for houses and family houses used for individual recreation, garages, structures for business activities, non-residential premises used for business activities and garages. The municipalities have the right to set this coefficient by their generally binding ordinance for particular types of structures. The value of the coefficient is at 1,5 and it multiplies the standard tax rate. Due to its fiscal function this coefficient is quite common in the Czech municipalities.

The municipalities enjoy new rights to increase the real estate tax from the beginning of 2009. A local coefficient at 2, 3, 4 or 5 can be set under a generally binding ordinance for all real estates in their area. This coefficient multiplies the tax duty of the taxpayer for particular kinds of lands, buildings, non-residential premises and flats. As the mayors say, taxes are political questions and mayors want to be elected again. Therefore, they do not want to use this coefficient and increase the taxes twice, three times, four times or even five times. However, there are some villages and towns like Dukovany - where the nuclear power station is built or in Brno, where the ordinances on local coefficient are prepared. 
The legal regulation of real estate taxation is still not perfect. We have to solve many problems not only with coefficients and exemptions. I have already written many times before, that the most urgent thing to do is to change the tax base - to replace existing unit taxation (taxes are calculated on units of the tax base, for example in $\mathrm{m}^{2}$ ) to ad valorem taxation (taxes are calculated on the price of the tax base, usually in national currency, expressed as percents). The tax base should correspond with the market value of the real estate. The value should be set by municipalities that have the best knowledge about the prices in their territory without any experts or assessors. The value can be used for transfer taxes or inheritance proceedings, too. The municipalities can create the map of value zones for the purpose of the real estate tax base. Anybody who is not satisfied with the price of his/her real estate set by the municipality, should have the possibility to appeal to the local financial office like in Denmark or in Ireland. The municipalities should have the right to set the tax rate but some intervals should be included in the act (for example $0,05-0,5 \%$ ). The other (usually higher) tax rate should be applied to development lands and the real estates which serve business activity. Lower tax rates can be used for the real estates like family houses and flats. The municipalities should be the only real estate tax administrators. This solution would mean modern European system of the real estate taxation and easier orientation for the taxpayers. The most important is the taxpayer: in his/her tax returns s/he should complete just identification data necessary to set the tax base. The tax administrators' task should be to set the tax base, calculate the tax and assess it.

It seems that there is no political will to solve the problems mentioned above. Instead of changing and modernizing the elementary structural items, the government wants to abolish exemptions for newly-constructed residential buildings and flats in newly-constructed residential buildings owned by individuals ${ }^{4}$ and exemptions for buildings which were reconstructed due to lower heat consumption. Especially the first change seems to be problematic and in my opinion it could even be unconstitutional: if an act gives me the right which is valid for a certain period (in this situation the right not to pay tax for fifteen years after buying e.g. a flat), can this right be abolished during this period?

\section{Transfer Taxes}

The most important change in transfer taxes (inheritance tax, gift tax and real estate transfer tax), introduced by the Act on Public Budgets Stabilization, is the exemption from inheritance tax and gift tax for persons in the first tax group (i.e. for direct relatives and spouses) and in the second tax group (i.e. other relatives and 
persons living with the decedent in one household for at least one year before the decedent's death and who took care of the common household or were dependent on the decedent's support). It means that inheritance and gift taxes are paid nowadays only by other natural persons and by legal entities, thus the administrative costs of the inheritance tax and gift tax are much higher than the revenue. The abolition of the taxes which include taxation of real burdens will be the next presumed step; real burdens were the subject to real estate transfer tax in 2007 and nowadays are taxed by the gift tax.

\section{Taxation of Motor Vehicles}

For many years the Czech legislator wanted the operators of new vehicles to fulfill ecological standards. The tax rate for vehicles in category EURO 2 was only $60 \%$ and for vehicles in category EURO 3 and higher only $52 \%$ of the standard tax rate. Every year this part of the act needed to be changed with respect to European regulations. However, during the discussions on the Act on Public Budgets Stabilization the question of the road taxation was completely forgotten. Therefore, the operators of new cars have no tax reductions now. The new rule of law compensating for existing situation is already signed by the President, but not published yet. ${ }^{5}$ The tax reduction $(48 \%$ for the next 36 calendar months from the date of their first registration, $40 \%$ for the period following the other 36 calendar months and $25 \%$ for the period following the other 36 calendar months) respects the date of registration and not the ecological limits. We must only believe that newly registered cars fulfill ecological and especially $\mathrm{CO}_{2}$ emissions limits. This regulation is retroactive, as it can be used even for the 2008 calendar year.

The road tax will have to be paid for all the vehicles of the total weight of at least 3,5 tons (nowadays 12 tons) from the beginning of 2009 .

\section{Conclusion}

To tell the truth, some changes are bad, some are better. Personally I agree with the new possibilities for municipalities to influence (increase or decrease) the real estate tax., however the most important problems have not been solved and I am afraid there is not enough political will to do that. The changes in the question of motor vehicles taxation are good, but coming a little too late. Many of the taxpayers have already paid advance payments and the tax administration will be (thanks to the legislators) more expensive, as tax offices will have to pay money back. The 
abolition of transfer taxes (inheritance and gift taxes) has been discussed for many years in the Czech Republic but I do not agree with it because these taxes are useful; on the other hand if the tax is unprofitable for the state, it is better to abolish it. 


\section{Streszczenie}

Celem artykułu jest wskazanie i analiza zmian regulacji prawnych dotyczących opodatkowania mienia, które odnoszą się do nowych możliwości samorządów miejskich w kwestii wywierania wpływu na opodatkowanie mienia, nowych wyjątków od opodatkowania dziedziczenia i opodatkowania darowizn dla członków rodzin oraz tendencji do zniesienia tych podatków w zupełności, redukcji opodatkowania nowych pojazdów silnikowych etc. Na podstawie tych zmian widać wyraźnie, że opodatkowywanie mienia powoli traci efekty i funkcje fiskalne nie tylko w Republice Czeskiej, a coraz większego znaczenia nabiera funkcja regulacyjna. 